Entrevista 


\title{
Economia solidária
}

\author{
ENTREVISTA COM PAUL SINGER
}

$\mathrm{E}$ CONOMIA SOLIDÁRIA foi o tema central da entrevista concedida por Paul Singer, professor aposentado da Faculdade de Economia e Administração da USP e titular da Secretaria Nacional de Economia Solidária, órgão vinculado ao Ministério do Trabalho e Emprego, a Paulo de Salles Oliveira, professor do Departamento de Psicologia Social e do Trabalho do Instituto de Psicologia da USP, e autor de Cultura solidária em cooperativas. Projetos coletivos de mudança de vida (São Paulo, Edusp/Fapesp, 2006), no dia 23 de setembro de 2007.

Paulo de Salles Oliveira - Paul, gostaria que você iniciasse explicando o que é economia solidária?

Paul Singer - Nós costumamos definir economia solidária como um modo de produção que se caracteriza pela igualdade. Pela igualdade de direitos, os meios de produção são de posse coletiva dos que trabalham com eles - essa é a característica central. E a autogestão, ou seja, os empreendimentos de economia solidária são geridos pelos próprios trabalhadores coletivamente de forma inteiramente democrática, quer dizer, cada sócio, cada membro do empreendimento tem direito a um voto. Se são pequenas cooperativas, não há nenhuma distinção importante de funções, todo o mundo faz o que precisa. Agora, quando são maiores, aí há necessidade que haja um presidente, um tesoureiro, enfim, algumas funções especializadas, e isso é importante sobretudo quando elas são bem grandes, porque aí uma grande parte das decisões tem que ser tomada pelas pessoas responsáveis pelos diferentes setores. Eles têm que estritamente cumprir aquilo que são as diretrizes do coletivo, e, se não o fizerem a contento, o coletivo os substitui. É o inverso da relação que prevalece em empreendimentos heterogestionários, em que os que desempenham funções responsáveis têm autoridade sobre os outros.

P. de S. O. - Qual seria a importância principal da economia solidária na sociedade brasileira atual?

P. S. - Ela basicamente demonstra que a alienação no trabalho, que é típica da empresa capitalista, não é indispensável. A heterogestão é justificada como eficiente a partir da visão de que alguns são mais capazes do que outros. A meritocracia justifica o poder de decisão estar concentrado no dono, o capitalista, depois em seus gerentes, enquanto a grande maioria é destituída de qualquer poder de decisão e mesmo de conhecimento sobre o conjunto. O raciocínio é circular: se o capitalista e seus gerentes têm mais poder, é porque o conquistaram e assim demonstraram ter mais capacidade. A maioria é destituída de poder porque deve ter menos capacidade. Esse raciocínio se sustenta no pressuposto de que numa economia de livre mercado os ganhadores na competição "têm" que ser os melhores, exatamente porque o mercado é livre, aberto a todos desde que tenham capital. Se muitos estão excluídos do mercado porque não têm capital, isso apenas confirmaria que eles são menos capazes. 
As pessoas que não têm capital e nem poder têm tarefas, poucas tarefas, e podem passar a vida inteira cumprindo as mesmas tarefas, o que é profundamente alienante do ponto de vista do desenvolvimento humano. O trabalho é uma forma de aprender, de crescer, de amadurecer, e essas oportunidades a economia solidária oferece a todos, sem distinção. Trabalhadores educados no capitalismo têm cada vez mais oportunidade de passar à economia solidária - isso está acontecendo, por exemplo, com empreendimentos que falham, entram em crise e os trabalhadores coletivamente os assumem organizados em cooperativas. Esse tipo de mudança representa a passagem da absoluta irresponsabilidade e ignorância em relação ao que ocorria na antiga empresa a uma nova situação, em que eles têm a responsabilidade coletiva pela nova empresa: se ela por algum motivo não ganha, eles também não ganham.

Eles não têm um salário assegurado no fim do mês que é uma das conquistas importantes dos trabalhadores no sistema capitalista, no qual eles não participam dos lucros e tampouco dos riscos. Agora, trabalhando em sua própria cooperativa, eles são proprietários de tudo o que é produzido, mas também os prejuízos são deles. Os trabalhadores no princípio estranham, e algumas vezes até reclamam, mas acabam por compreender que essa é uma experiência libertadora. Quando os trabalhadores passam alguns anos praticando autogestão, mesmo que algumas vezes o empreendimento vá mal, eles preferem continuar na economia solidária a procurar uma oportunidade de trabalhar numa empresa capitalista.

\section{Cooperativa de economia solidária e cooperativa de fachada}

P. de S. O. - Sabemos que a marca registrada da economia solidária está nas cooperativas. No entanto, existem no Brasil algumas cooperativas que são meramente fachada. Gostaria que você explicasse qual a diferença entre uma cooperativa de economia solidária e uma cooperativa de fachada e, se possivel, se há alguma estimativa das proporções em que elas existem no Brasil?

P. S. - O que você está chamando de cooperativa de fachada nós chamamos de coopergatos ou cooperfraudes, e elas são um número enorme e por uma razão essencial: as cooperativas na legislação brasileira são consideradas associações de trabalhadores autônomos e, conseqüentemente, a cooperativa não tem nenhuma responsabilidade sobre o ganho e os direitos sociais de seus próprios sócios. $\mathrm{Na}$ cooperativa não há salário mínimo nem Fundo de Garantia por Tempo de Serviço, férias, $13^{\circ}$ salário e os demais direitos trabalhistas. Isso é um erro de uma legislação obsoleta, que nós estamos tratando de corrigir. Existe hoje um Projeto de Lei 7.009 de 2006 do presidente Lula, tramitando no Congresso, que obriga as cooperativas a garantirem a seus sócios os direitos trabalhistas básicos, que são direitos humanos. Mas a aprovação desse projeto infelizmente ainda vai levar tempo.

As muitas falsas cooperativas que hoje infestam o país são empreendimentos capitalistas que simplesmente pagam aos seus trabalhadores, pro forma "seus sócios", apenas o salário direto, ou seja, o dinheiro que o trabalhador leva para casa. Hoje os chamados encargos indiretos representam algo próximo da metade do pagamento total que os trabalhadores recebem dos seus empregadores. Então, é extremamente sedutor para um empresário transformar a sua firma numa pseudocooperativa e praticamente reduzir pela metade o seu gasto com a folha de pagamentos. Existem hoje até consultoras especializadas em transformar empresas em falsas cooperativas. 
Os trabalhadores são todos demitidos, recebendo seus direitos e são logo avisados: "Olhem, se inscrevam na cooperativa e vocês continuarão trabalhando amanhã e vão continuar recebendo os mesmos salários que estão ganhando". Porque é apenas disso que normalmente o trabalhador toma conhecimento: o salário que ele leva para a casa. Só que os demais direitos eles não recebem mais. Isso hoje é uma peste; não só firmas capitalistas, mas também universidades e hospitais estão fazendo isso. Se professores querem dar aula ou se médicos querem dar plantões, eles têm que se inscrever em falsas cooperativas e renunciar a todos os direitos sociais, exceto o recebimento de um pagamento, que muitas vezes é inferior ao salário mínimo ou ao mínimo profissional.

É hoje uma espécie de infecção que pega todos os setores da economia. A fiscalização procura combatê-la, mas ela segue a doutrina que qualquer trabalho, que é semelhante ao trabalho assalariado, tem que ser assalariado. Então, tendem a fechar mesmo as cooperativas autênticas porque são cooperativas e por suposto não asseguram aos trabalhadores os direitos legais, obrigatórios apenas para os assalariados.

Isso tem sido mais do que um entrave, um desafio. Um desafio muito grande, porque tais direitos básicos do trabalhador - trabalhar em segurança, não perder a saúde no trabalho, ter assegurado Fundo de Garantia por Tempo de Serviço que é uma espécie de auxílio desemprego etc. - são absolutamente essenciais hoje. São normas internacionais, instituídas por convenções da Organização Internacional do Trabalho (OIT), e aprovadas pela maioria dos países. O intenso crescimento da economia solidária não pode ser confundido com a disseminação das falsas cooperativas, pois isso significaria transformar os trabalhadores de economia solidária em trabalhadores de segunda classe.

Infelizmente, muitas das cooperativas formadas por trabalhadores sofrem de escassez de capital e insuficiente acesso aos mercados, de modo que se vêem forçados a competir sacrificando seus próprios membros, embora isso em geral ocorra apenas nos primeiros tempos. Nessas circunstâncias, nossos próprios trabalhadores não querem ser regulados Mas isso é um erro deles. Em países como França, Itália, Espanha, a legislação obriga as cooperativas de trabalho a observarem a legislação do trabalho, pelos mesmos motivos que nós estamos tentando aprovar o Projeto de Lei 7.009/06 aqui no Brasil.

A política adotada pelos países europeus é justa porque alinha as cooperativas de trabalho com os sindicatos de trabalhadores na luta contra a precarização das relações de trabalho. Inclusive, ela é justa para as empresas capitalistas, pois, quando elas concorrem com cooperativas, não deveriam ser obrigadas a pagar praticamente o dobro do que o trabalhador recebe e a cooperativa não, pois assim a cooperativa ganharia todas as concorrências, à custa do sacrifício de conquistas históricas de todos os trabalhadores.

É um assunto complexo, que levamos anos discutindo no Ministério do Trabalho. Discutimos também com a Organização das Cooperativas Brasileiras (OCB) e com nossas grandes federações de cooperativas, como a União Nacional das Cooperativas da Agricultura Familiar e Economia Solidária (Unicafes) e a Confederação das Cooperativas de Reforma Agrária no Brasil (Concrab) do Movimento dos Trabalhadores Rurais sem Terra (MST). A Unicafes é uma união de mais de mil cooperativas agrícolas e tem, entre as suas muitas cooperativas, várias de agrônomos que fazem 
extensão rural e apóiam cooperativas de economia solidária. Fazem seu trabalho, organizam-se como cooperados, mas não conseguem ganhar o mínimo profissional de agrônomos, embora recebam bem acima do salário mínimo porque são profissionais universitários. Para enfrentar esses problemas, nosso projeto de lei prevê um programa de fomento, de apoio às cooperativas de trabalho. É o Programa Nacional de Fomento ao Cooperativismo do Trabalho (Pronacoop), em que primeiro dá-se um prazo para que a cooperativa se adapte e passe a garantir os direitos trabalhistas para os seus sócios. Durante esse prazo, as cooperativas receberão assistência do governo para atingir plena suficiência econômica, necessária para cumprir a legislação. Elas receberão apoio para oferecer mercadorias ou serviços de mais qualidade, além de também terem acesso a crédito, tecnologia etc. Não temos nenhum interesse de ter uma economia solidária miserável, muito pobre. Mas essa é a realidade da economia solidária no Brasil hoje. Quer dizer, houve essa enorme crise, o nome que vocês queiram dar nas relações de trabalho, e isso veio desde os anos 1990, desde Collor e, especialmente, desde o Plano Real, então houve uma precarização muito grande e o cooperativismo está sendo usado. Não são só as falsas cooperativas, há outras formas também de fraudar a legislação.

P. de S. O. - Existe uma possibilidade de quantificar isso, aproximadamente quantas falsas cooperativas?

P. S. - Não, não temos a menor chance. Nós estamos fazendo um mapeamento da economia solidária e o último resultado recente desse banco de dados é o de que nós estamos com 22 mil empreendimentos de economia solidária no país. Isso é bem mais do que a gente havia imaginado. Em 2005 tínhamos levantado quinze mil.

P. de S. O. - De qualquer forma, é bem menos do que as cooperativas de fachada?

P. S. - Nós não temos idéia. Por exemplo, a Organização das Cooperativas do Brasil (OCB) fala em 26 mil cooperativas no Brasil, mas ela mesma tem um terço disso como número de filiadas. Quantas dessas cooperativas são de fachada e quantas são autênticas? Eu acho que é impossível saber. Qual o tamanho do contrabando no Brasil? Da pirataria?

\section{Clubes de troca}

P. de S. O. - E o clube de troca, Paul? Gostaria que você explicasse o que é, como funciona, por que ele existe, e qual é a sua importância.

P. S. - O clube de troca foi criado em situações de crise, crise de mercado de trabalho. Ele surgiu em vários lugares. Na América do Norte, na Ilha de Vancouver, em que havia uma base aérea e acho que uma fábrica. A população trabalhava nesses lugares e os dois fecharam de repente; todos ficaram sem trabalho. Um inglês, que morava lá, sugeriu organizar trocas entre eles; quer dizer, eles trabalhariam uns para os outros, para todos poderem viver, comer etc. Mas, para fazer essa troca, era preciso organizar um mercado e um sistema de preços, então ele sugeriu criar uma moeda especifica para essa atividade. Essa foi a invenção do LETS (Local Exchange and Trade System).

Os argentinos passaram por muitas crises nos anos 1990. Lá inventou-se o que nós chamamos hoje de clube de troca. Como o neoliberalismo acarretou crises sociais, com desemprego em massa e exclusão social, clubes de troca ou LETS difundiram-se por muitos países de todos os continentes, e pelo Brasil também. Eles 
permitem à pessoa sem trabalho, ou com pouco trabalho, aumentar suas vendas e simultaneamente suas compras, e em conseqüência produzir mais, se alimentar melhor e satisfazer outras necessidades. Um clube de troca típico, aqui na América Latina, se compõe de profissionais liberais, médicos, psicanalistas, músicos, mas também jardineiros, motoristas de táxi, empregadas domésticas, cozinheiras etc.

E esse grupo tem um traço em comum: eles não conseguem vender seus serviços na medida em que gostariam, todos têm capacidade ociosa. Então se reúnem, geralmente uma vez por mês, e cada um diz o que faz, o que pode fazer e de que bens ou serviços tem necessidade. Não são serviços apenas; um violão que não está sendo usado ou um aposento vago podem ser alugados para quem deles estiver precisando. Depois que as pessoas enunciaram suas ofertas e demandas, elas entram em processo de troca.

Mas, para que trocas sejam possíveis, é preciso que as pessoas que querem adquirir alguma mercadoria possam fazê-lo antes mesmo de terem vendido as mercadorias que constituem sua oferta. Como a grande maioria carece de dinheiro, o processo de intercâmbio não poderia deslanchar porque ninguém poderia comprar antes de vender. Esse ponto de estrangulamento monetário é superado pela adoção pelo clube de uma moeda própria, que, em geral, ganha um nome fantasia, com caráter ideológico, como: reais solidários, dólares verdes ou horas [de trabalho]. Antes de cada sessão de trocas, cada sócio recebe a mesma quantia da moeda do clube. Com esse dinheiro, as primeiras mercadorias são compradas. $\mathrm{Na}$ medida em que as compras e vendas se realizam, a moeda do clube vai trocando de mãos, até que todos os desejos de compras e vendas estejam realizados.

A Argentina, em 2001, passou por uma crise monetária muito grave e milhões de pessoas ficaram sem trabalho, e, portanto, sem conseguir viver. Então, as pessoas vendiam o que tinham para poder comer.

Já havia, então, grande quantidade de clubes de troca. Naturalmente, os que precisavam vender algo para poder comprar alimentos e outros bens e serviços essenciais procuravam os clubes de troca para obter um crédito inicial na moeda do clube, e assim poder adquirir mercadorias.

Estimava-se na época que cerca de sete milhões de pessoas se serviram de clubes de troca. Eles se multiplicaram velozmente pelo país e muitos usavam o mesmo papel-moeda, vendido pelos criadores originais dos clubes de troca. Como não havia nenhum controle dessa nova moeda social, pessoas sem escrúpulos aproveitaram a ocasião e falsificaram-na. A profusão de moeda social multiplicou a demanda pelas mercadorias ofertadas nos clubes de trocas, ocasionando uma vasta inflação de preços em moeda social. Como resultado, grande parte dos clubes de troca cerrou as portas.

Hoje os clubes de troca estão se reconstituindo na Argentina numa situação muito melhor. Além disso, a economia do país começou a se recuperar ainda em 2001 e desde então vem crescendo intensamente. Em países mais ricos, os desempregados não morrem de fome, de modo que nos LETS o que menos se troca são bens e serviços. Em vez disso, o que há é muita troca de idéias e muita festa, pois os socialmente excluídos carecem de vida social, uma vez que não têm mais os contatos que o trabalho regular suscita. Assim, os LETS ou clubes de troca desempenham outros papéis, além da satisfação de necessidades econômicas. 


\section{Empresas de autogestão}

P. de S. O. - Você falou de uma empresa que acabou fechando e depois foi assumida pelos trabalbadores em autogestão. Gostaria que você falasse um pouco mais dessa iniciativa de empresas que acabam se tornando dos trabalhadores e que são autogeridas por eles.

P. S. - Essa é uma experiência antiga. Na época de Karl Marx, ou seja, no século XIX, já havia empresas desse tipo. No começo dos anos de 1870, uma crise de conjuntura fez que várias minas de carvão fechassem, e as cooperativas de consumo dos trabalhadores fabris compraram essas minas, reabriram-nas e passaram a operá-las. Experiências análogas parecem ter acontecido em muitos outros países. No Brasil, começou a haver quando, nos anos 1980 , por causa da crise da dívida externa, algumas grandes empresas fecharam. Um caso importante, ocorrido então, foi objeto de tese de doutoramento da professora Lorena da Silva, defendida na USP. Tratava-se da crise da fábrica de fogões Wallig, que na época era a maior fábrica de fogões do Brasil. A empresa empregava três a quatro mil pessoas. Foi uma tragédia ela fechar. Produzia um fogão de elite, caro, com grande prestígio em todo país.

O desemprego de tanta gente mobilizou a prefeitura e o governo do Estado, que se empenharam em tentativas de salvar a empresa, mas em vão. No entanto, surgiu a idéia de que os ex-empregados organizados poderiam arrendar o patrimônio da empresa falida e passar a operá-la. Só que ninguém tinha a menor idéia de que tipo de pessoa jurídica poderia representar tantos trabalhadores e de forma eqüitativa. Foram à procura de um caso análogo e acabaram descobrindo uma cooperativa que trabalhava para empresas de sapatos, no interior do Rio Grande do Sul. Conseguiram o estatuto dela e descobriram que a cooperativa é a forma de que necessitavam, e assim, eles praticamente reinventaram a economia solidária, por pura necessidade.

Essa cooperativa, da Wallig, existe até hoje. Ocorreram na mesma época outros casos, mas inteiramente esparsos, não conhecidos no resto do Brasil. Portanto, não houve nos anos 1980 um processo de disseminação. Entre esses casos isolados, um dos mais emblemáticos foi o da mina de carvão, em Criciúma, que os mineiros ocuparam e ameaçaram explodir com eles dentro, se ela fosse fechada. A Cooperminas já tem vinte anos de funcionamento e ajudou os trabalhadores de outros empreendimentos em crise a assumi-los e recuperá-los, na forma de cooperativas.

Mas, tudo mudou em 1992, quando quebrou uma grande empresa de calçados, a Makerli, em São Carlos (SP). Também dessa vez, os sindicatos convocaram os trabalhadores para ver se eles ficavam com a empresa e vários técnicos do Departamento Intersindical de Estatística e Estudos Socioeconômicos (Dieese) foram ajudar os trabalhadores. ${ }^{1}$ Os trabalhadores, que assumiram a Makerli, orientados pelos técnicos do Dieese, criaram então a Associação dos Trabalhadores em Autogestão e Participação Acionária (Anteag). O nome faz referência ao modelo americano que, no entanto, não se adapta à realidade brasileira, mesmo porque aqui a legislação não oferece nenhum incentivo à compra de empresas pelos empregados. $\mathrm{O}$ movimento começou com a Makerli porque a criação de uma "fábrica sem patrões" tornou-se famosa no Brasil inteiro e virou objeto de peregrinação. Pessoas de várias partes do Brasil iam a Franca para ver a fábrica que funcionava sob a autogestão dos operários, sem patrões. 
Desse momento em diante, o Dieese passou a ser consultado por sindicalistas de todas as partes do país a respeito de como evitar que empresas em processo falimentar fossem fechadas e como fazer para que os ex-empregados pudessem assumi-la na forma de cooperativa. Foi para atender a essas demandas de forma sistemática que a Anteag foi criada em 1994.

A Cooperativa Makerli funcionou vários anos, à base de capital de giro fornecido pela Caixa Econômica Estadual, a atual Nossa Caixa. Mas, em 1994, houve a mudança de governo paulista, a Caixa deixou de financiar a cooperativa e ela acabou fechando. Mas, nessa altura, já havia a Anteag e as empresas conhecidas como "recuperadas" se multiplicaram, sobretudo quando, em julho de 1994, o Plano Real abriu completamente a economia à importação de mercadorias (sobretudo asiáticas) e milhões de postos de trabalho industrial foram perdidos. As empresas recuperadas são hoje centenas e de todos os tamanhos, sendo algumas emblemáticas como a já mencionada Cooperminas, a Uniforja em Diadema (SP) e a maior de todas, a legendária Usina Catende, em Pernambuco.

P. de S. O. - Agora, a grande dificuldade é imaginar os trabalhadores na condução dos negócios, na administração e mesmo na colocação dos produtos no mercado. São atividades que escapam à habilidade normal de cada um dos operários, dos trabalbadores em geral. Como eles resolvem isso?

P. S. - Em primeiro lugar, pelo que se sabe, algumas pessoas da administração ficam. A maior parte sai, não aceita a autogestão, mas há alguns engenheiros, principalmente pessoas de esquerda, que ficam. Em alguns empreendimentos grandes, como o da Uniforja, todos os mestres das diversas seções ficaram com a cooperativa.

P. de S. O. - Você poderia falar da Uniforja?

P. S. - Fica em Diadema, era a maior forjaria da América Latina, fornecia peças pesadas, sobretudo para a Petrobras. Houve vários problemas da família proprietária, inclusive a morte do fundador. São sempre empresas antigas, que ao quebrar são assumidas pelos ex-empregados, porque os trabalhadores também são antigos, lutaram juntos décadas a fio e por isso têm muita confiança mútua. Isso foi fundamental para que os trabalhadores conseguissem assumir a empresa, porque representa uma tremenda responsabilidade para eles, inclusive investir seus créditos trabalhistas para comprar o patrimônio. Agora, na essência a resposta à sua pergunta é o auto-aprendizado, o autodidatismo. Estou convencido hoje de que as coisas melhores que nós sabemos nós aprendemos fazendo, e não em aula. Talvez eu esteja saindo do assunto...

\section{P. de S. O. - Acho que é importante você continuar.}

P. S. - Penso que a escola comete um pecado mortal e imperdoável porque ela separa totalmente a teoria da prática. Ela vem com a teoria seca, não há preocupação em que o aluno faça, aplique a teoria; ele só precisa decorá-la e logo mais esquece tudo o que aprendeu, pois não tem aplicação prática e ele nem consegue articulá-la ao conjunto dos conhecimentos anteriormente obtidos. Ele acaba apagando esse conhecimento, porque só atrapalha. O conhecimento da escola traz algumas coisas básicas, claro: ler, escrever, fazer tabuada etc. Mas o resto a gente aprende fazendo.

Há um nítido aumento de escolaridade dos trabalhadores das empresas atualmente recuperadas, mas eles conseguem aprender a administrá-las bem porque eles 
são acompanhados pela Anteag e pela União e Solidariedade das Cooperativas e Empreendimentos de Economia Social no Brasil (Unisol). Hoje elas também formam redes de cooperativas e têm recursos, ou o governo os fornece, para contratar assessoria tecnológica, financeira, legal e fiscal. Além disso, o processo de auto-aprendizado é muito rápido porque ele deriva do próprio trabalho realizado. Então, esses trabalhadores que não tinham acesso nem ao conhecimento muito menos às responsabilidades começam a colocar o empreendimento de pé, a reconquistar antigos clientes e antigos fornecedores.

\section{Pluralidade e rede comum de interesse}

P. de S. O. - Eu vejo que você falou já da Unisol, da Anteag, da Unicafes, da Concrab, só não falou da Unitrabalho, mas enfim, forma-se uma sopa de letrinhas. Evidentemente que eu imagino que cada uma delas tenta colaborar, às vezes no setor rural, outras no urbano. Mas gostaria que você falasse um pouco dessa pluralidade e se isso, por exemplo, chega a convergir numa rede comum de interesse das pessoas que possam se beneficiar com a economia solidária. Em que medida essa pluralidade divide ou ela caminha para uma rede?

P. S. - Obviamente, é a segunda opção. Ela caminha para uma rede. Nós temos hoje algo que é objeto no exterior de muita admiração e até é espantoso e que só existe no Brasil, pelo que eu sei. Nós temos um "Fórum Brasileiro da Economia Solidária" que praticamente abrange tudo que há de economia solidária no país: todos os tipos de empreendimentos de economia solidária, todas as ONG e movimentos sociais que apóiam a economia solidária e que se servem dela como maneira de enfrentar os problemas sociais e econômicos; e os gestores públicos, municipais e estaduais que executam políticas de apoio à economia solidária. Todos estão no mesmo Fórum; então essa diversidade a que você está se referindo é observável cada vez que ele se reúne. Ele é muito ativo, faz reuniões regionais, organiza reuniões plenárias.

Já há muito tempo o movimento inteiro vem tentando construir redes - redes econômicas de cooperativas de segundo grau, cadeias produtivas organizadas. Pregamos isso aparentemente no deserto por anos, muito antes de surgir a Secretaria [Secretaria Nacional de Economia Solidária - Senaes], porque as cooperativas isoladamente são muito frágeis. A maior parte é de gente muito pobre, não tem acesso a capital; tem difícil acesso ao mercado e também não tem acesso ao conhecimento, embora eles voltem à escola. Mas, como nós vimos, a escola não é tão eficaz assim. Agora, finalmente, depois de vários anos, estão surgindo cada vez mais redes de cooperativas. Um caso emblemático é a Justa Trama.

P. de S. O. - Seria importante que você explicasse...

P. S. - É uma cadeia produtiva, que começa no Ceará, com agricultores orgânicos que cultivam algodão. Eles também têm uma cooperativa que separa o caroço da pluma; a pluma vem para uma empresa recuperada aqui em São Paulo, que a fia. Depois uma outra empresa recuperada faz os tecidos e, finalmente, há um número maior de cooperativas de confeccionistas, costureiras, que transformam esses tecidos em uma grande variedade de produtos para serem vendidos. Essa cadeia já constitui uma cooperativa de segundo grau, ou seja, se integraram. São cooperativas autônomas, mas elas se articularam para serviços comuns, formando uma cooperativa de segundo grau. É uma bela experiência e não é única. Já temos a Renace, que é uma 
federação de grandes cooperativas metalúrgicas de São Paulo, Rio Grande do Sul e Minas Gerais. Existem também redes de cooperativas de apicultores, fruticultores e artesãos.

\section{Complexo Cooperativo de Mondragón}

P. de S. O. - Quando você fala de cooperativa de segundo grau, o que isso quer dizer?

P. S. - As cooperativas têm essa tendência a se unir, inclusive é um dos princípios universais hoje. A Aliança Cooperativa Internacional, que é a união política de todas as cooperativas do mundo, revisa periodicamente os princípios universais do cooperativismo. Tendem a repetir os originais do século XIX, mas há novos, e um deles é a intercooperação, ou seja, as cooperativas devem cooperar entre si. No mundo capitalista, os mercados são dominados por gigantescas empresas, que resultam da contínua fusão de empresas menores; as cooperativas só conseguem competir se elas também se unem.

O caso mais famoso é o Complexo Cooperativo de Mondragón, no País Basco, na Espanha. São mais de uma centena de cooperativas, em que setenta mil pessoas trabalham hoje, e formam um complexo de cooperativas singulares, de segundo grau, de terceiro grau etc. No Brasil, um caso famoso que não é bem da economia solidária é uma cooperativa de médicos, a Unimed. Ela é a maior prestadora de serviços médicos privados no Brasil. Esse sistema é formado por cooperativas de médicos municipais, que se unem numa cooperativa de segundo grau em cada Estado, e essas 27 cooperativas estaduais formam a Unimed do Brasil, que é uma cooperativa de terceiro grau.

Esse tipo de associação de cooperativas é uma união econômica, não política. Determinados serviços são prestados pela cooperativa de segundo grau às suas sócias, as cooperativas singulares. Pode ser propaganda, assessoria jurídica, serviço de contabilidade etc. As cooperativas de crédito singulares são afiliadas a uma central que forma uma cooperativa de segundo, terceiro graus dependendo dos âmbitos, mas sempre dentro de uma lógica econômica; ou seja, a cooperativa de nível mais alto presta serviços às cooperativas sócias.

P. de S. O. - Você falou em Mondragón e eu me lembro de suas aulas em que você falava com verdadeira paixão do padre Arizmendi. Gostaria que você falasse como surge um padre dentro de um complexo cooperativo no País Basco.

P. S. - A Espanha, que era uma república democrática, acaba sendo vítima de um golpe militar, e após sangrenta guerra civil (1936-1939) torna-se uma ditadura fascista, que se prolonga por quarenta anos, até 1976, até a morte de Franco. O padre Arizmendi era um seminarista na época da Guerra Civil Espanhola e lutou na guerra, no lado republicano. Foi preso e não foi fuzilado por muito pouco. Ele resolveu dizer a verdade, que ele realmente era um combatente e, por falar a verdade, ele foi preservado e, enfim, solto. Um amigo dele, que disse que era jornalista e só estava cobrindo a guerra, foi fuzilado porque não acreditaram. Ele era basco e Franco oprimiu o quanto pôde os bascos: inclusive proibiu o uso de sua língua. Em Mondragón, as cooperativas surgem num momento de resistência nacional e democrática contra a ditadura fascista. O padre era um discípulo dos grandes autores, Maritain, Mounier, do socialismo cristão. 
Mondragón nos anos 1950 era uma cidade industrial muito pobre. O padre Arizmendi começou a criar uma escola técnica, para dar qualificação profissional aos filhos dos operários. Em 1956, ele ajudou a um grupo de cinco ex-alunos a criar uma primeira cooperativa que fabricava fogões, como a Wallig. Deu muito certo, eles começaram não só a fazer a montagem dos fogões, mas também a fabricar as peças e depois eles desdobraram a cooperativa. Uma das preocupações do padre Arizmendi e seus companheiros era de que uma cooperativa muito grande deixaria de ser democrática. Eles imaginavam cooperativas de no máximo cem pessoas, que se pudessem conhecer pessoalmente. Essa primeira cooperativa tem hoje três a quatro mil membros.

Dessa matriz foram desdobradas cooperativas que se dedicam à forjaria e a outras especialidades. A escola técnica tornou-se uma Politécnica e hoje integra a Universidade de Mondragón (também uma cooperativa). O padre Arizmendi fez as cooperativas industriais fundarem a Caja Laboral Popular, hoje um dos maiores bancos do país, e incorporou uma cooperativa de consumo, que hoje é a maior rede de supermercados da Espanha. Arizmendi promoveu a fundação de cooperativas de pesquisas científicas, que trabalham para muitas cooperativas industriais e onde estagiam doutorandos em física, química etc. da Espanha inteira. Integra o Complexo ainda uma cooperativa de seguros que presta serviços previdenciários para todos os trabalhadores do Complexo.

O Complexo Cooperativo de Mondragón forma o maior conjunto de cooperativas de trabalho do mundo, que administra de forma autogestionária as atividades de dezenas de milhares de trabalhadores, hoje não mais só em Mondragón, mas também em outros países. Recebemos recentemente a visita de uma professora da Universidade de Mondragón, que fez uma exposição para a equipe da Secretaria Nacional de Economia Solidária sobre problemas de Mondragón. Ela nos enviou recentemente um artigo de um colega dela, da Universidade de Mondragón. Ele diz que Mondragón está em crise, uma crise dos valores da economia solidária, do cooperativismo. A situação mudou completamente, da época heróica em que Mondragón foi criada, dos primeiros anos em que o padre Arizmendi comandou o processo e hoje. O padre conseguiu convencer os trabalhadores a não ficar com nenhuma parte das sobras; as sobras eram inteiramente investidas por causa do dever ético de criar o máximo de número de postos de trabalho, em razão do elevado desemprego de então. Hoje isso não existe mais, inclusive na região de Mondragón existem empresas capitalistas que professam os princípios de Mondragón, portanto são participativas.

Os empresários muitos deles estudaram na Universidade de Mondragón e é uma instituição muito influente hoje na Espanha e em outros países também que tentam emular o cooperativismo de Mondragón. Agora, além de eles não serem mais pobres, a opressão também é menor; o Movimento Separatista Pátria Basca e Liberdade está legalizado, a luta para obter a independência formal se trava no plano político e a língua basca é ensinada e praticada. Então, das motivações originais para se criar as cooperativas em Mondragón a que sobrou é a melhor: ter uma economia de iguais, em que todos participam, todos são responsáveis, todos estão informados. $\mathrm{Na}$ análise desse professor, essa filosofia também está em crise porque ela, de alguma maneira, se opõe às necessidades de competir hoje no capitalismo neoliberal, que é hegemônico na comunidade européia, da qual a Espanha faz parte. Então, estão sentindo que ou adotam os princípios capitalistas ou não conseguem progredir e podem até fechar. 
Não há a opção de ficar do jeito que estão: ou se avança ou se acaba sendo expulso do mercado.

Agora o Complexo de Mondragón investe onde a mão-de-obra é barata, o que em nada está de acordo com os princípios. No Brasil, por exemplo, eles têm sucursal e um representante, assim como na China, na Checoslováquia, no México, lugares em que os direitos trabalhistas são poucos e os salários são baixos. É o que todos fazem, o capitalismo todo está indo para a periferia. Acontece que, nesses países, Mondragón cria empresas capitalistas e hoje explora o trabalho dos que ali residem; eles praticam a democracia no País Basco, mas fora não. Isso cria problemas seriíssimos para eles do ponto de vista de consciência; quer dizer, se são contra a exploração, como é que fazem isso? Um argumento usado por eles é o de que não encontraram espírito de economia solidária em outros países, os trabalhadores não conhecem essa cultura.

Obviamente, essa é uma má desculpa; em todos esses países há cooperativas de trabalho. Aqui, no Brasil, agora é diferente, eles têm uma acordo com o MST, nada mais, nada menos. O MST manda todo ano pessoas para Mondragón para ficarem vários meses lá, e Mondragón manda intelectuais deles para aprender conosco. Literalmente querem aprender as grandes experiências da economia solidária no mundo e o Brasil é um dos lugares em que eles querem aprender mais, por isso já recebemos vários professores, entre os quais Aynoa, uma professora muito simpática, jovem. No seminário que deu, ela explicou que o centro de pesquisa de que faz parte reconhece que há uma crise no Complexo e, para enfrentá-la, estão convocando para março de 2008 um seminário de "Testemunhos dos Principais Movimentos de Economia Solidária do Mundo" para ver o que se pode aprender deles. Eu fui convidado a participar dele e pretendo comparecer, porque com certeza há muito a aprender num encontro dessa dimensão.

Acho que Mondragón é um exemplo fundamental porque teve muito êxito econômico de um lado e há essa crise de valores, mas que eles reconhecem com muita franqueza e a discutem. O Complexo realiza congressos periodicamente, em que reafirmam os seus propósitos, seus princípios; quer dizer, eles não aceitam a crise de braços cruzados, como uma coisa fatalista. Poderiam se conformar dizendo que o mundo é assim, foi uma bela experiência de várias gerações, mas que agora não dá mais.

\section{As cooperativas e a legalidade}

P. de S. O. - Paul, en gostaria de entrar agora em alguns problemas da economia solidária no Brasil. Você acabou de citar um que eu desconbecia: que é esse fato de que entidades estrangeiras passam a investir em economia solidária no Brasil porque a mãode-obra é barata. Mas penso também nas questões jurídicas ligadas às próprias cooperativas existentes. Sendo a economia solidária um caminho alternativo, que problemas isso traz do ponto de vista jurídico? Por exemplo, como as cooperativas podem ter um estatuto jurídico legal, que thes permita nas licitações estarem juridicamente em igualdade ou pelo menos sem suspeição para participarem dessas licitações?

P. S. - Isso é regulado hoje pela Lei n. 8.666, que basicamente cria condições de igualdade entre os diferentes tipos de empreendimentos. As cooperativas são legais no Brasil, inclusive constitucionalmente elas devem ser fomentadas, portanto devem gozar de uma situação privilegiada, de acordo com certo consenso político. Por causa 
das falsas cooperativas, o governo federal fez com o Ministério Público do Trabalho um acordo de conduta que exclui as cooperativas de trabalho da possibilidade de concorrer por uma longa lista de serviços terceirizados, sobretudo os mais humildes como limpeza, transporte, cozinha, manutenção, jardinagem etc. Acontece que muitas cooperativas disputam exatamente esse tipo de trabalho. Por quê? Porque elas não precisam cumprir a legislação do trabalho e assim ganham todas as licitações. Isso é fato verdadeiro e constitui uma precarização das relações de trabalho. As verdadeiras cooperativas também tendem a precarizar porque a lei não as coíbe de fazer isso; há um grau de auto-exploração, os trabalhadores ficam muito ansiosos para ter clientes. Se elas podem oferecer um preço mais baixo, oferecem.

Eles sabem que a cooperativa não tem que obedecer às leis trabalhistas, portanto a gente pede o máximo que pode, mas que pode ser bem abaixo do que seria o mínimo necessário. Então essa é a situação no setor público. Isso foi um dos motivos que nos levaram à legislação para regular o cooperativismo do trabalho. Hoje muitas cooperativas que tinham contrato de prestação de serviços a algum órgão da administração pública, quando se abre uma nova licitação, não podem entrar por causa desse termo de ajuste de conduta. Se elas trabalhavam unicamente para o poder público, a sua exclusão pode acarretar seu fechamento.

Sugeri ao governo federal mudar o Termo de Ajuste de Conduta (TAC) $)^{2}$ no sentido de que se admitam as cooperativas com a condição de cumprir rigorosamente toda a CLT, para colocá-las na mesma condição dos concorrentes capitalistas. O que é justo, mas nós não conseguimos ainda colocar em prática e está no Congresso esse Projeto de Lei n. 7.009 que tornará obrigatório para as cooperativas de trabalho o respeito a determinados direitos legais dos trabalhadores, como o salário mínimo, duração da jornada, condições de salubridade no trabalho etc.

Nós temos, no Conselho Nacional de Economia Solidária, um comitê temático, para o marco jurídico, porque a Lei Geral do Cooperativismo n. 5.764 é antiga, de 1971. Ela praticamente não prevê cooperativas de trabalho porque na época não existiam no país e em vários outros aspectos ela precisaria ser atualizada, mas existem impasses políticos, sobretudo no que se refere à representação política do cooperativismo. A Organização das Cooperativas do Brasil, a OCB, monopoliza hoje a representação do cooperativismo brasileiro. $\mathrm{Na}$ época do regime militar, a OCB era praticamente estatal. Hoje ela é uma associação voluntária privada, que assumiu a curiosa forma de sindicato. A OCB é um sindicato de cooperativas. E ela se registrou como sindicato patronal; ninguém sabe disso porque não tem importância pública. A OCB adotou essa atitude para poder criar o Serviço Social das Cooperativas (Sescoop). Para tanto, eles tiveram que se adaptar à Lei do Serviço Social, segundo a qual só os sindicatos patronais é que geram os Sesi, Sesc, Senai, Senac. Então hoje temos o Sescoop, que presta serviços às cooperativas, embora seja sustentado por contribuições sobre a folha de pagamento de cada cooperativa. Em analogia com as demais entidades do sistema "S", o Sescoop teria de prestar serviços aos empregados das cooperativas.

Enfim, há uma base jurídica que é essa legislação de 1971. Embora feita no regime militar, ela transcreve no corpo da lei os princípios universais do cooperativismo da época, da Aliança Cooperativa Internacional, e isso é importante, pois ela dá base para eventualmente fechar as falsas cooperativas, desde que se consiga demonstrar 
que elas não são verdadeiras cooperativas, que seu dono é uma pessoa e não os que fazem o trabalho e que formalmente são os associados.

P. de S. O. - Mas essa preocupação não é muito mais da Senaes e dos órgãos vinculados à economia solidária do que propriamente da $O C B$ ?

P. S. - Não, a OCB está muito empenhada numa nova legislação geral do coo-perativismo. Há um projeto de lei tramitando no Senado desde a promulgação da atual Constituição, em 1988. Mas, cada vez que um novo Congresso é eleito, todos os projetos de lei que ainda não foram aprovados ou recusados são arquivados. Mas nada impede que no começo da nova legislatura ela seja reapresentada. A OCB tem um projeto de lei geral do cooperativismo. O senador Eduardo Suplicy apresentou outro projeto, com o apoio da economia solidária. Isso começou antes da criação da Senaes.

Agora, uma nova legislatura se abriu e o senador Suplicy reapresentou o projeto dele com muitas inovações. Além disso, o governo também está fazendo seu projeto. No grupo de trabalho encarregado disso, o Fabio Sanches, secretário adjunto da Senaes, representa o Ministério do Trabalho. E, com todo esse esforço, acho que em breve o governo vai apresentar um projeto de lei que provavelmente terá o apoio tanto da OCB como do movimento de economia solidária. Então, os outros dois projetos possivelmente serão retirados ou fundidos. Essa é a boa perspectiva.

Agora, com o "Supersimples", ${ }^{3}$ criou-se um mercado privilegiado para as micro e pequenas empresas nas compras públicas. Isso é uma novidade no Brasil: em compras até oitenta mil reais, micro e pequenas empresas, que são definidas como tais pela sua receita anual, passam a ter uma chance a mais. Se apresentaram um preço superior ao preço menor que normalmente venceria a licitação, sendo a diferença não maior que $10 \%$, elas têm o direito de ficar com a encomenda, desde que baixem o seu preço, ao preço da empresa que antes seria ganhadora.

Nós descobrimos, graças ao mapeamento, que 98\% dos nossos empreendimentos de economia solidária são ou micro ou pequenas empresas, de acordo com sua receita anual. Mas a lei do "Supersimples" aprovada excluía de seus benefícios as cooperativas, exceto as de consumo. O que era injusto. Então, o deputado Tarcisio Zimmermann, em colaboração com a Senaes e o Conselho Nacional de Economia Solidária, apresentou uma emenda, que já está aprovada e sancionada, pela qual todas as cooperativas (exceto as de crédito) podem se beneficiar do "Supersimples".

Além disso, grande parte da economia solidária é rural e ela se beneficia também do programa de aquisição de alimentos do governo federal. É um programa que está se expandindo muito e é fundamental porque compra a produção da agricultura familiar, desde que ela se organize. Não há como comprar de cada agricultor; são milhões, individualmente. Mas, se eles se organizarem numa cooperativa, numa associação, a Companhia Nacional de Abastecimento (Conab) do Ministério da Agricultura compra a produção de cada família até o limite de 2.500 reais. Esse programa começou em 2004 com algumas centenas de milhares, e hoje são dois milhões de famílias que vendem a sua produção. Também compram artesanato, não compram só alimento. Porque as famílias camponesas fazem muito artesanato: geléias, lingüiças e outros tipos embutidos, bonecas e enfeites. Os camponeses tratam de processar o que eles produzem para poder vender por um valor maior, pois eles precisam ganhar mais dinheiro. 


\section{Crédito e economia solidária}

P. de S. O. - Parece-me que a questão do crédito está vinculada a essa discussão jurídica. Sendo a economia solidária uma atividade alternativa, ela muitas vezes não se encaixa nas possibilidades de crédito existentes ou, onde está adequada, as taxas são muito onerosas para as cooperativas da economia solidária. Como fica a questão do crédito na economia solidária? Quais os problemas e o que tem sido feito nesse sentido?

P. S. - Esse é provavelmente o maior gargalo, o maior desafio para a economia solidária: deixar de ser miserável e poder se tornar próspera. É o acesso ao capital, que os empreendimentos de economia solidária não têm... porque são pobres. Mas não têm acesso ao sistema financeiro porque o sistema financeiro é antipobre, tradicionalmente. O sistema financeiro formal está muito voltado aos grandes clientes, sejam governos ou empresas. Há um dito que banco só empresta para quem não precisa. Isso é verdade, porque quem precisa mais é quem não tem como garantir que vai devolver o que tomou emprestado; então o sistema exclui os pobres. Toda uma luta contra a exclusão financeira está sendo travada pela economia solidária. O microcrédito é uma da armas principais, e sua massificação foi inventada em Bangladesh.

P. de S. O. - Bangladesh, se me permite um parêntese, mostra exatamente o contrário do que você está dizendo, ou seja, são pessoas que não tinbam garantias de que os empréstimos seriam pagos e que, no entanto, o grau de inadimplência, segundo você mesmo mostrou pelo livro do Yunus, ${ }^{4}$ foi minimo, não é isso?

P. S. - É, segundo Yunus, a taxa de inadimplência é zero. O banco do Yunus, que é o Grameen Bank - banco da aldeia -, é uma tremenda cooperativa de crédito: os donos do banco são os clientes do banco e são elas, pois, noventa e tantos por cento dos sete milhões de clientes do Grameen Bank são mulheres; os únicos homens admitidos pelo Grameen são aqueles que são chefes de famílias em que não há mulheres. $\mathrm{O}$ crédito é concedido a grupos de cinco pessoas, que devem decidir juntas quanto cada uma delas deve receber. Cada grupo se reúne semanalmente para recolher as prestações destinadas a repagar a dívida. Nessas reuniões, as mulheres trocam idéias e experiências e, se alguma está em dificuldade para pagar a prestação, as demais ajudam.

Houve uma interpretação capitalista do sistema do Yunus no sentido de que o grupo de cinco seria um grupo de aval, aval solidário. Eles não têm aval, pois Yunus parte da idéia - e está convicto disso - de que ninguém no sistema Grameen deixa de pagar quando pode. Se não paga é porque não pode, e, se não pode, o problema não é processar, é dar mais dinheiro para eles para poderem se reabilitar. Inclusive o país é notório pelas inundações: na época das monções, o país sofre de inundações trágicas incessantemente. Então a quantidade de gente que não consegue pagar deve ser enorme quando ocorrem as monções; eles já sabem disso e financiam a reconstrução. Depois as pessoas pagam. Dessa forma, o microcrédito é um sistema financeiro extraordinário, em que o índice de inadimplência é zero, ou seja, ninguém deixa de pagar o que deve.

P. de S. O. - As mulheres têm alguma coisa a ver com isso?

P. S. - Bem, o argumento básico do Yunus é de que a mulher é quem cuida dos filhos; os homens têm menos consideração pelas necessidades dos outros membros da família, são mais egoístas, e então a possibilidade de que o proveito do crédito seja mais usufruído por eles é maior. Dando crédito à mulher, é mais garantido que toda 
família se beneficie. E há um segundo argumento de que, na religião muçulmana em particular, as mulheres são muito oprimidas. Hoje, há uma importante organização internacional chamada Banco da Mulher, que faz microcrédito só para mulheres. O feminismo foi adotado pelo microcrédito, graças ao Yunus.

\section{A experiência do microcrédito no Brasil}

P. de S. O. - E aqui? O microcrédito no Brasil está vinculado à economia solidária?

P. S. - O microcrédito chegou ao Brasil através de organizações bem capitalistas, que nos trouxeram uma versão modificada do sistema do Grameen, que foi promovida muito pelo Serviço Social de Apoio à Micro e Pequenas Empresas (Sebrae) e pelo Banco Nacional de Desenvolvimento Econômico e Social (BNDES), na época do presidente Fernando Henrique. Essa versão do microcrédito aposta no espírito de empreendedorismo individual, incentiva as pessoas pobres a se tornarem empreendedoras. Pressupõem que os melhores dão certo e o microcrédito deve ajudar os melhores. Então é uma visão oposta da economia solidária, e a idéia, inclusive, é de que o microcrédito deve ser concedido por organizações autônomas, que devem se sustentar, quer dizer, devem ser economicamente auto-suficientes, o que implica cobrar juros e taxas dos clientes em medida suficiente para cobrir todos os custos, para poder crescer e acumular capital.

As Organizações da Sociedade Civil de Interesse Púbico (Oscip) têm alguns privilégios, tais como poder prestar serviços públicos não-estatais, mas têm também algumas obrigações de transparência. A grande maioria dos prestadores de microcrédito no Brasil foi criada sob essa forma jurídica e o problema grave é esse: eles têm que ser sustentados pelos seus clientes, que são paupérrimos. Isso é quase impossível porque os empréstimos são de pequeno valor e têm que ser acompanhados por agentes de crédito, que têm que ganhar alguma coisa. Então, na verdade a conjunção das Oscip ao microcrédito sai muito caro. Eles cobram $4 \%$ ao mês e a alternativa é o agiota que cobra muito mais. E além disso, eles cobram taxas de abertura de conta, o que faz que o custo do empréstimo para o tomador chegue a $5 \%$ ou $6 \%$ ao mês. E a escola do Yunus preconiza que isso não deve ser assim; o crédito, na fase inicial, pode ser subsidiado. No Grameen Bank foi subsidiado pelo governo de Bangladesh, mas hoje o Grameen Bank chegou a uma situação em que não tem mais nenhum dinheiro externo; quer dizer, o capital é inteiramente das sete milhões de mulheres e eles estão criando empresas, mais ou menos solidárias, de várias espécies em Bangladesh com o lucro do banco. Isso é uma história de pouco mais de trinta anos, que começou em 1976.

P. de S. O. - Ogoverno brasileiro tem sido sensivel às suas demandas e da Secretaria no sentido de dirigir créditos específicos para organizações da economia solidária?

P. S. - Tem sido porque a Secretaria está profundamente empenhada nisso e há o apoio dos grandes bancos públicos federais, e acho que os estaduais também. É o caso do Banco Nacional de Desenvolvimento Econômico e Social (BNDES), que está agora mudando a sua metodologia para poder atender às empresas recuperadas. Essas empresas recuperadas, as maiores e mais importantes, não têm problema de venda; pelo contrário, elas têm tido mais demanda do que podem atender, e aí acontece uma coisa paradoxal: ou você atende a essa demanda ou eles vão comprar de outro forne- 
cedor. Então a cooperativa acaba perdendo clientes e pode até vir a quebrar depois. Por isso, elas entraram no BNDES com pedido de recursos para fazer investimentos e ampliar a capacidade.

O BNDES normalmente leva meses para atender a pedidos de financiamento, mas não para cooperativas. Aí ele leva anos. Porque esse tipo de cliente está completamente fora do padrão com que o BNDES está acostumado. Ele foi criado para financiar governos ou empreendimentos de grande porte. Esse tipo de cliente oferece garantias "sólidas" porque é um multibilionário que está à frente da empresa, quando ela é privada, ou se é do governo é o próprio tesouro público que dá a garantia. Eles não podem dar crédito a uma cooperativa que é sucessora de uma empresa quebrada porque ela não pagou as dívidas do antecessor.

Há quatro anos, criou-se um Departamento de Economia Solidária no BNDES e também uma linha especial de crédito, dirigida às empresas cooperadas. Eles obviamente querem emprestar, e para tanto se propõem a reduzir o montante de garantias. Geralmente a garantia exigida é de $150 \%$ do valor do empréstimo; para as empresas recuperadas ela foi reduzida a $70 \%$. Fizeram uma série de outras facilidades e, mesmo assim, não conseguiram fazer qualquer empréstimo. Mas eles não conheciam de fato as cooperativas de economia solidária, o que lhes impedia de avaliar o risco corretamente. Enquanto isso, os empreendimentos, achando que iam receber o crédito, na ânsia de atender aos pedidos, acabavam tomando dinheiro praticamente a juros de usurário, que é crédito de curto prazo pagando de 5\% a 10\% por mês. Eles imaginavam que iriam pagar isso por pouco tempo, se expandindo com o dinheiro do $\mathrm{BN}$ DES que viria, e, assim, substituiriam uma dívida extorsiva por outra para pagar $6 \%$ a $7 \%$ ao ano. Só que o dinheiro do BNDES não vinha. Então, de repente, nós ficamos com as maiores empresas de economia solidária em crise.

Voltamos ao BNDES, fizemos um seminário dentro do banco sobre economia solidária. Fiz uma exposição tentando convencê-los de que a autogestão é eficiente, mas que, evidentemente, os nossos empreendimentos carecem de capital, precisam ser ajudados. Agora existe um trabalho tripartite, BNDES, Senaes e as grandes federações de cooperativas - a Unisol e a Anteag -, e estamos construindo um sistema que vai permitir financiá-los.

Já os nossos empreendimentos agrícolas estão sendo salvos pelo Programa Nacional de Fortalecimento da Agricultura Familiar (Pronaf). O governo brasileiro realmente criou crédito acessível, e subsidiado se necessário, à agricultura pobre e miserável do país. Isso se iniciou na época do presidente Fernando Henrique, mas, segundo me contaram, praticamente limitado ao Sul do Brasil. E, na verdade, a grande necessidade também era no resto do país, mais pobre, e o governo Lula estendeu isso ao país inteiro. O valor dos créditos do Pronaf, que era de dois bilhões na época do Fernando Henrique, subiu para dez a onze bilhões. Ele está atendendo realmente ao conjunto da agricultura familiar, a juros de $2 \%$ ao ano, e os mais pobres têm um abatimento de $25 \%$ do valor; quer dizer, é subsidiado. Além disso, estão criando novas linhas, todas elas emancipatórias, como o Pronaf-Mulher, o Pronaf-Jovem. É um grande programa de microcrédito, créditos pequenos para gente pobre. Esse microcrédito é público, funciona, e uma das aspirações do movimento de economia solidária é estendê-lo às cidades: fazer um Pronaf urbano. Há trabalhos nessa direção. 


\section{Economia solidária e exclusão social}

P. de S. O. - Muitos conbecem a economia solidária como um recurso destinado às pessoas que foram excluidas do mercado de trabalho - não só os mais pobres, mas sobretudo esses. E ela tem sido acusada de ser uma espécie de reparadora dos malefícios dessa lógica perversa do mercado. Gostaria de saber o que você pensa disso.

P. S. - O que eu posso dizer é que essa foi efetivamente a função que a economia solidária realizou no Brasil nos anos 1990, e continua realizando agora, e é a razão de seu crescimento muito vigoroso. Ela tem uma função social; está efetivamente inserindo as pessoas na produção e na vida social. Há uma preocupação particular com os jovens, tanto do presidente Lula quanto da Senaes, no sentido de dar uma oportunidade aos jovens de periferia e de baixa escolaridade, que estão ociosos e caindo no crime. Falo dos homens, não das mulheres. As mulheres continuam estudando, mas eles abandonam as escolas porque acham que não têm serventia, e uma parte acaba indo para o crime. Mas essa não é a função fundamental da economia solidária.

Esperamos um dia eliminar a grande pobreza do país, e os dados da Pesquisa Nacional por Amostra de Domicílios (PNAD), de 2006, dão boas esperanças de que isso venha a acontecer. O "Fome Zero" já cumpriu sua função; hoje praticamente ninguém passa fome no Brasil. Reduzimos o número de pobres, na porcentagem da população geral, de uma forma tão acentuada entre 2005 e 2006 que eu acredito que vamos ter menos de $10 \%$ de população pobre no fim deste mandato do presidente Lula, se a redistribuição mantiver esse ritmo. Agora, como eu disse no início, a economia solidária não se limita a isso; ela propõe uma outra economia, uma economia desalienante, que oferece ao trabalhador e ao conjunto das pessoas um ambiente de trabalho muito melhor, mais igualitário em vez de hierárquico. Isso interessa tanto aos camponeses e artesãos como aos profissionais universitários, artistas, cientistas etc.

Como já mencionei antes, a economia solidária encontra adeptos também na classe média. Nós temos cooperativas de profissionais de classe média, desde a Unimed até os agrônomos, que têm hoje cooperativas. Tanto no Movimento dos Trabalhadores sem Terra como na Unicafes, há muitos exemplos. Além desses, há jornais cooperativos, e na área cultural, sobretudo, há muitas cooperativas de teatro, de cinema. Por falar nisso, no Ministério da Cultura há um programa chamado "Cultura Viva", dirigido principalmente a jovens de áreas faveladas e periféricas. Fazem um edital e os grupos se apresentam com sua produção, que pode ser artesanal, de pintura, música, dança, o que for. Hoje há quase setecentos pontos culturais no país todo, mas querem chegar a milhares. E a idéia é usar a produção cultural para inclusão produtiva. Estão fechando um acordo conosco e querem que nós passemos a capacidade de auto-organização da economia solidária para esses pontos de cultura. Já fizemos uma Feira Nacional de Economia Solidária junto com os pontos de cultura num evento chamado "Teia Cultural", que aconteceu no edifício da Bienal em São Paulo em 2006 e se repetiu em Belo Horizonte, em 2007, criando-se uma articulação entre os empreendimentos de economia solidária e os pontos de cultura, que querem também fazer economia solidária.

Espontaneamente, surgiram feiras em vários pontos do Brasil, unindo os empreendimentos de economia solidária com gente pobre e os pontos de cultura, que rece- 
bem do Ministério da Cultura equipamentos para reproduzir som e imagem. Então, a função integradora num país em crise, numa sociedade em crise, é primordial, no momento. Mas a minha perspectiva é a de que, superados os problemas da miséria e da pobreza - e acho que isso pode se dar em pouco tempo -, a economia solidária terá uma imensa função no país.

O caso de Mondragón, entretanto, mostra que isso não é uma certeza. Mondragón continua sendo basicamente economia solidária, mas está com problemas graves. Por exemplo, estão usando cada vez mais trabalho assalariado temporário dentro de Mondragón para atender à demanda. Como ninguém é despedido em cooperativas, se ela tiver grandes mudanças de demanda ao longo do ano, acaba tendo dificuldades de fazer que o excesso de pessoas, quando não há muito trabalho, sobreviva. Então, estão empregando assalariados, mas isso é uma distorção que vai contra os princípios, na verdade. Nosso grande interesse, igual ao de Mondragón, é entender e adaptar a economia solidária a uma situação de não-miséria. E não permanecer na necessidade de socorro. Agora, existem teóricos da economia solidária que a vêem como uma parte compensadora dentro do capitalismo. Acreditam que o capitalismo está aí para ficar, mas que necessita, como contrapeso aos seus exageros - desigualdade, criação de miséria -, de uma economia solidária, apoiada no estado. Laville defende isso com todas as letras. Não é meu ponto de vista.

P. de S. O. - Um ponto forte de seu pensamento se refere à possibilidade da economia solidária como ruptura. Uma das propostas, das mais instigantes, também partiu de seus textos, que é a possibilidade de existência, com o crescimento da economia solidária, de dois modos de produção distintos, convivendo na sociedade. Com isso, se promoveria uma verdadeira revolução social, mas uma revolução inteiramente pacífica, ou seja, sem derramamento de uma gota de sangue. Não seria pela via da violência. Seria pela via da democracia e da emancipação dos sujeitos, que teriam essa possibilidade de escolba entre um modo e outro. Essa proposta me parece verdadeiramente fascinante. Entretanto, sempre sobra quem nos diga que muito maior do que essa possibilidade é acontecer a absorção da economia solidária pela economia de mercado. Gostaria de ouvir o que você tem a dizer.

P. S. - Eu volto à discussão de Mondragón. É o nosso único exemplo de grande escala, em que a economia solidária chegou a fundar um outro modo de produção e não há dúvidas em torno disso hoje na Espanha. Não é só no País Basco; é também na Catalunha. Mondragón é como um modelo. Temos também, no Brasil, situações em menor escala, mas semelhantes. Renascem alianças de grandes metalúrgicas, que fazem navios, trens aqui no país. Além disso, existe Catende, que foi objeto de reforma agrária e receberá investimentos.

A dúvida é essa: desaparecendo a compulsão econômica, as pessoas, de livre vontade, optarão por uma formação coletiva e igualitária ou preferirão a irresponsabilidade, ou seja, um bom emprego, em que você faz uma certa carreira e o empregador cuida de você. Embora, hoje, no capitalismo liberal, você tenha que cumprir metas e metas, cada vez mais extenuantes. As condições de trabalho, no capitalismo, estão piorando nos dias atuais. Enfim, são dois modelos e isso que você mencionou é uma realidade, em alguma medida até aqui no Brasil, também. Mas, na Europa, mais ainda. O fundamental é que as pessoas possam optar: não acredito que se deva destruir o capitalismo. Gostaria que ele fosse abandonado espontaneamente. 
É diferente da escravidão: ela teve de ser abolida porque era trabalho forçado. O capitalismo não é trabalho forçado; as pessoas optam por um emprego ou então, se houver uma economia solidária ao lado, a pessoa pode optar por aderir a alguma organização associativa autogestionária ou criar uma com amigos, colegas etc. Essa opção sempre existiu, nós não a inventamos. E os dados concretos mostram que a opção pela economia solidária ou pelo cooperativismo mundial não é insignificante. Hoje, $10 \%$ da população do mundo estão em cooperativas vinculadas à Aliança Cooperativa Internacional. São entre seiscentos a setecentos milhões de pessoas, principalmente na agricultura. A agricultura mundial é dominada por cooperativas, mas não só. Também ocorre com todas as áreas de prestação de serviços: educação, saúde... Se você ler a literatura sobre o cooperativismo mundial, verá que ele é extremamente vigoroso. Mas com ele estão todos os problemas que apontamos na discussão de Mondragón. São cooperativas que tendem ao gigantismo, se burocratizam e perdem uma parte de sua motivação original.

Isso é um fato. Interessante que os partidos operários passaram exatamente pela mesma coisa; os grandes sindicatos operários passaram pela mesma coisa. Então, estamos falando, na verdade, de processos que eu chamaria de degenerativos por uma questão de valor. Mas, se você quiser ser um cientista social bem objetivo, diria que são processos de mudança. As gerações mudam. Hoje as gerações que trabalham em Mondragón, cinqüenta anos depois, não são as que criaram o Complexo; são os filhos e netos.

O caso mais lancinante, a meu ver, de crise e de abandono de um grande movimento de economia solidária foi o dos kibutzim. Eles estão ficando assentamentos residenciais. As pessoas continuam morando juntas porque é bom, mas a grande maioria trabalha fora do kibutz; só mora junto. E aí acontece uma coisa fantástica: o kibutz quer virar um investimento imobiliário capitalista. Mas o guardião das fundações em Israel diz: "Não, vocês não podem. Porque a terra é do Estado e foi cedida a vocês para fazer economia solidária. Então, se não querem fazer mais, saiam”. A crise no movimento dos kibutzim é muito semelhante a essas crises que estão por aí. A meu ver, seria suicida negar isso, fechar os olhos e dizer que não têm importância. Têm importância! O problema do kibutz - trata-se de um caso extremo, mas muito interessante - é que por razões ideológicas eles não têm aposentadoria. Ninguém se aposenta em kibutz, ou seja, você vive e, na medida em que vai ficando mais velho, trabalha menos, trabalha até onde você pode, e se você ficar doente e não puder trabalhar mais o kibutz o sustenta da mesma forma. Portanto, não há necessidade de aposentadoria. Mas isso supõe que os filhos e netos continuem no kibutz. Se, agora, os filhos e os netos abandonarem os kibutzim em massa, qual será seu futuro? Quem vai sustentá-lo quando você não for mais capaz? Essa foi uma das razões da crise.

P. de S. O. - Se a economia solidária se coloca como resistência, é preciso que ela manifeste cada vez mais a capacidade de resistir...

P. S. - Ela não é resistente. A meu ver, ela propõe uma coisa diferente. É uma outra proposta, mas tem muito a ver com valores. Quer dizer, nós chegamos numa época da humanidade em que estamos tão bem economicamente que as pessoas podem optar. No momento em que esses kibutzim antigos estão realmente passando por uma crise total, jovens estão formando novos kibutzim nas cidades. E na Europa inteira estão surgindo comunas semelhantes ao kibutzim; há centenas delas. Conheci 
uma de perto, em Kassel. Existem ali, nas universidades, até incubadoras de economia solidária. Ali perto existe uma comuna de umas cem famílias; são muito ecológicos e muito de esquerda. Têm uma ideologia socialista e são militantes políticos.

Eu mencionei isso em aula, na USP, quando eu ainda dava aulas, e um aluno, Felipe Banitz, disse: "Professor, mas temos muitas comunas no Brasil!". As nossas são de fundo religioso, muitas vezes, mas não necessariamente cristão ou católico. Existe uma do movimento do calendário Maia. Depois eu fui prestar atenção e efetivamente a juventude experimenta formas coletivas de viver. Essa discussão é importante; no dia em que deixar o governo, pretendo me dedicar mais a isso. Se for apenas para atender às insuficiências do capitalismo, a economia solidária poderá continuar existindo, mas terá um papel absolutamente secundário de atenuador de contradições.

Os desafios da Secretaria Nacional de Economia Solidária (Senaes)

P. de S. O. - Sei que a Secretaria Nacional de Economia Solidária realizou um mapeamento de empreendimentos solidários no Brasil e gostaria muito que você contasse quais foram as principais descobertas.

P. S. - O mapeamento está sendo feito desde o início da Secretaria; era uma aspiração antiga do movimento realizar algum tipo de survey da economia solidária no país. A ida ao governo federal permitiu fazer isso. Há recursos e esse mapeamento é feito de uma forma inteiramente democrática, ou seja, em cada Estado há um comitê gestor. Os intelectuais, os pesquisadores da economia solidária participam desses comitês. O levantamento é feito profissionalmente, e os resultados formam um banco de dados que pode ser atualizado a qualquer momento. Novas cooperativas e novos empreendimento de economia solidária podem se registrar, atualizar.

Mas existem partes do país que nós não conseguimos visitar ainda, de modo que provavelmente a economia solidária é maior do que os 22 mil empreendimentos solidários que nós conseguimos entrevistar. Para nós, politicamente é importantíssimo isso, mas também economicamente, porque nós temos hoje 22 mil empreendimentos com endereço eletrônico, com mapa e com o que fazem. Constituem o Sistema de Informações da Economia Solidária (Sies). Está regulamentado e os resultados estão disponíveis para consulta no site do Ministério do Trabalho.

O Sies facilita a articulação entre cooperativas e a formação de redes, federações, parcerias econômicas que eventualmente culminam na criação de cooperativas de segundo grau. Deve estar sendo usado para atrair as cooperativas produtoras do mesmo tipo de mercadoria, como apicultores, fruticultores ou quebradeiras de coco. Mas também ela permite politicamente a reivindicação de recursos, considerando a expressão desses 22 mil empreendimentos, que são sustentados pelo trabalho de um milhão e setecentos e cinqüenta mil pessoas, o que já não é insignificante, considerando que é uma coisa recente no Brasil. O Ministério do Trabalho tem um acordo com o Instituto de Pesquisa Econômica Aplicada (Ipea) que permitiu sustentar uma série de investigações sobre empreendimentos de economia solidária, cujos resultados foram essenciais para se fazer políticas adequadas de apoio a diferentes formas da economia solidária.

A economia solidária brasileira está ficando extremamente diversificada. Na medida em que nós estamos cobrindo o território nacional através da extensão do Fórum Brasileiro de Economia Solidária, a gente começa a descobrir, por exemplo, 
muitos quilombos. Temos mais de mil quilombos já reconhecidos no país e quase todos eles se sentem atraídos pela economia solidária, porque seus valores coincidem, em boa medida, com os valores da economia solidária. E os quilombos são muito diferentes; eles têm em comum que são comunidades negras rurais que ficaram certo período isoladas. Mas um quilombo na Amazônia ou um quilombo de Porto Alegre provavelmente são muito diferentes.

Há quilombos de pescadores, de extrativistas, de agricultores, e assim por diante. Há comunidades indígenas que estão vindo agora para a economia solidária. Descobri recentemente que indígena é um conceito exclusivamente de branco. Não há indígena para os indígenas porque eles têm seus povos, têm suas línguas, têm sua religião, que não têm nada a ver com a língua e a religião do outro. Então, o mapeamento nos permite efetivamente conhecer o Brasil, isto é, um corte do país, da sociedade brasileira. É extremamente importante para o conhecimento científico brasileiro. Cada vez mais há trabalhos de doutoramento e de mestrado sobre economia solidária. Tenho participado de muitas bancas, você provavelmente também, e a universidade está se envolvendo profundamente com a economia solidária.

Existem 43 universidades com Incubadoras de Cooperativas Populares. Abrimos um edital para mais universidades e oitenta se apresentaram. Fizemos um seminário para dar a eles uma idéia do que se trata e nem todas puderam vir. Já foi aprovada a formação de 37 novas incubadoras. Para a luta pela economia solidária, as incubadoras são essenciais e cada vez mais outros ministérios estão apoiando as incubadoras, não só a Senaes. Enfim, a sua pergunta sobre mapeamento significa qual é a relação entre a economia solidária e o que nós estamos chamando hoje de sociedade da informação. E eu diria que ela está em total afinidade; o fato de se valerem da internet é essencial para manter as redes funcionando, mas, além disso, uma das coisas importantes é que nós hoje incorporamos gradativamente o movimento nacional do software livre. Eles já se reconhecem na economia solidária. Estive numa reunião enorme de software livre, com sete mil pessoas em Porto Alegre, uma reunião latinoamericana, e fizeram uma sessão só sobre economia solidária em que ficou evidente que os princípios do software livre são os nossos, e vice-versa.

\section{As universidades e as incubadoras de cooperativas populares}

P. de S. O. - Paul, você falou nas incubadoras e seria importante que você se estendesse nisso para explicar o que são essas incubadoras de cooperativas populares. Como elas atuam? Como elas estão ajudando a economia solidária?

P. S. - Bom, as incubadoras são projetos de extensão universitária. Algumas universidades brasileiras fazem um trabalho de apoio a pobres no seu próprio meio, isso é muito comum, ou mesmo em áreas mais pobres dos seus respectivos Estados - no norte de Minas, no Vale da Ribeira, e assim por diante -, de modo que as incubadoras se inserem numa atividade de promoção social, de resgate social das universidades. Elas são especificamente de economia solidária, significa que elas acompanham e ajudam a criar novos empreendimentos de economia solidária e, ao mesmo tempo, trazem para dentro da universidade essa experiência concreta. Isso muda o ambiente na universidade, sobretudo quando a incubadora é forte, tem alunos de todos os cursos. Isso traz uma novidade porque a universidade normalmente tende a se concentrar nos futuros empregadores dos seus estudantes. Esse é o público para o qual 
a universidade tende a dar atenção, é o chamado mercado. Mas é preciso considerar que uma grande parte da população não está nesse mercado e não tem dinheiro. Então, as incubadoras de certa forma estendem o interesse, a curiosidade, a atividade de pesquisa das universidades ao universo dos excluídos.

P. de S. O. - Ela seria uma forma de aprender fazendo, como você falou?

P. S. - Isso, perfeitamente. Há um imenso aprendizado dos próprios estudantes. Isso eu vejo agora nas Senaes, uma boa parte das pessoas que trabalham nela vêm diretamente de incubadoras e são ótimas. Não só trazem a experiência do auto-aprendizado, como se dispõem a batalhar pela economia solidária; são militantes.

P. de S. O. - Ouvi recentemente, em uma das cooperativas que visitei, a queixa de que o conbecimento universitário, mesmo que tenha criado as incubadoras, ainda é pouco. A universidade deveria gerar alguma tecnologia, que viesse diretamente contribuir para alguns desses problemas que a gente acabou de discutir. Então, estuda-se muito economia solidária, mas o que a universidade oferece concretamente para a resolução dos principais problemas da economia solidária ainda é irrisório. O que você pensa disso?

P. S. - Não estou de acordo. Acho que a universidade dá a sua contribuição através das incubadoras. Existe uma rede, hoje, de tecnologia social que o governo sustenta e que existe precisamente para criar e difundir tecnologias para a inclusão social. Ainda que muito pouco se faça na universidade, isso se faz em vários lugares, inclusive nos próprios empreendimentos, que descobrem novas tecnologias fazendo. Não quero subestimar a importância científica do que a universidade faz, mas a pobreza desses empreendimentos cria uma distância muito grande entre eles e a maior parte da tecnologia que hoje se cria, pela vanguarda da pesquisa. E que se aplica apenas a grandes organizações, públicas ou privadas. Há casos de inovação técnica aplicada nos nossos maiores empreendimentos, como Catende. Ali se mudou a cana que se plantava por uma cana de melhor qualidade, graças a um técnico cubano que trabalha lá e que trouxe uma tecnologia que está se desenvolvendo em Cuba..

P. de S. O. - A experiência de Catende é importante. Você poderia explicar em poucas palavras o que é exatamente?

P. S. - Catende é uma agroindústria de açúcar. Tem mais de cem anos e, desde 1995, trabalha em autogestão devido à falência dos antigos donos da empresa. Depois de funcionar como autogestão durante doze anos, a terra e as benfeitorias foram objeto de uma expropriação para fins de reforma agrária. A massa falida está agora em vias de se tornar dos próprios camponeses e dos trabalhadores da indústria. É muito grande; são 28 mil hectares, quatro a cinco mil famílias moram lá, formando uma comunidade de treze, quatorze mil pessoas. Está organizada em autogestão, isto é, uma forma democrática de gerir tudo isso juntos. Optaram por não dividir a metade da terra, que será cultivada por todos coletivamente. Estão diversificando a produção e vão começar a produzir um álcool neutro, para uso em cosméticos, e já existe uma empresa no Japão interessada nisso; a Petrobras está intermediando.

Acho que o futuro econômico de Catende vai ser muito interessante, e aí as inovações cientificas provavelmente encontrem aplicação devido ao tamanho do empreendimento e ao seu potencial econômico. Agora, pequenos empreendimentos artesanais, extrativos ou agrícolas, estão muito longe de poder aproveitar as inovações produzidas na universidade, e eu acredito que é uma crítica injusta para a universidade dizer que ela não contribui. 


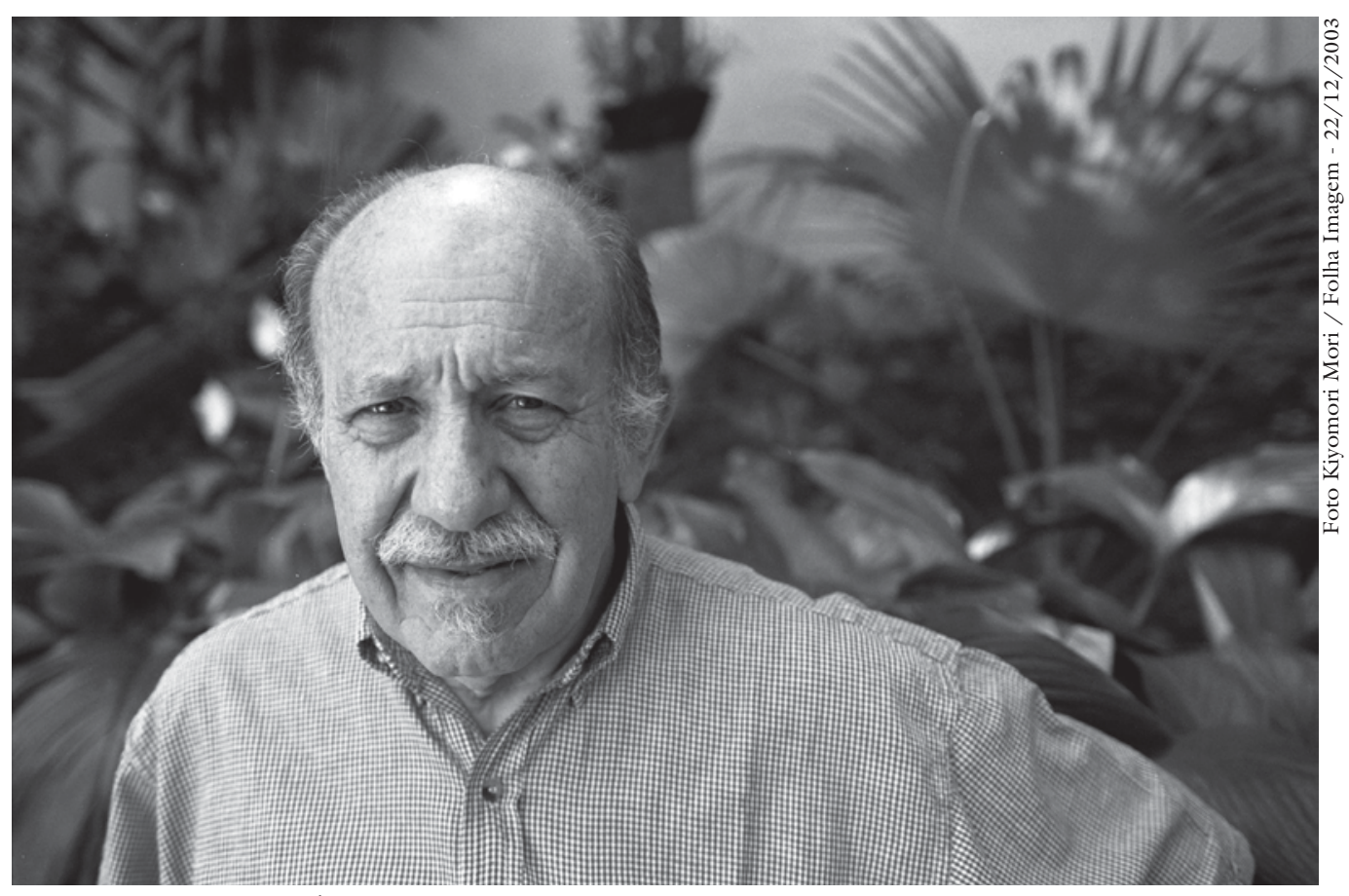

O economista Paul Singer.

\section{Experiência de engajamento e atuação}

P. de S. O. - Eu queria agora, Paul, tratar do seu engajamento pessoal com a economia solidária. A sua vida tem sido dedicada à economia solidária seja na universidade seja no poder público seja a cada minuto da existência. Então, gostaria que você pudesse contar quais as principais razões que levaram você a esse engajamento.

P. S. - Bem, eu vou ver se eu torno a resposta o mais sintética possível, senão vou ter que contar minha vida inteira. Mas, quando eu tinha dezesseis anos, entrei num movimento de jovens judeus que pretendiam formar um kibutz em Israel e morar lá. Portanto, a primeira formação socialista que eu tive na minha vida era exatamente de economia solidária, ligado, no entanto, com noções de que era preciso formar partido, tomar o poder, destruir o capitalismo. Quando eu saí desse movimento em 1952, eu tinha vinte anos; saí por razões pessoais, mas, sobretudo, porque eu não acreditava no sionismo. Eu achava que para lutar contra o anti-semitismo seria melhor lutar em cada país do que reunir os judeus parcialmente num único país. Isso está gerando problemas trágicos agora que já estavam de certa forma se manifestando naquela época.

Aí me tornei militante socialista no Brasil, inclusive sindical, depois na universidade, como dezenas de milhares no Brasil. Eu sou um militante de esquerda como tantos outros e fui secretário do Planejamento aqui em São Paulo, ocupei cargos de direção no Partido Socialista, depois no PT; enfim, durante toda a vida fui militante político. E aquilo que seria a economia solidária da minha adolescência ficou um pouco no meu subconsciente. Relendo agora coisas que eu escrevi há uns dez anos antes de se cunhar a palavra (não por mim), já havia em germe a preocupação. A experiência stalinista de socialismo foi trágica. Não foi apenas defeituosa: ela de socialismo não tinha coisíssima nenhuma, era só pretensão Toda a nossa geração passou 
por isso e até conseguir chegar à conclusão de que não era socialismo levei vinte anos; outros levaram provavelmente outras décadas.

Ao me convencer de que Marx errou, vi que a idéia de centralizar o planejamento de toda a economia nacional num único grupo de dirigentes é profundamente antidemocrática e viola os direitos humanos, ou seja, não era uma boa idéia. Ela estava levando o capitalismo com suas tendências de concentração do capital às últimas conseqüências. E ele sabia disso, só que achava que desembocaria no reino da liberdade. Na prática, não se mostrou nem um pouco isso. Mas, se esse não era o socialismo, o que era socialismo? Essa foi a indagação que me ocupou nos anos 1980. Num de meus livros chamado Aprender economia, há um capítulo chamado "Socialismo". Era um curso que eu dei no Rio e, graças a Deus, no livro existe não só o que eu expus, mas também as respostas às perguntas da platéia. Ali já estão idéias de economia solidária sem esse nome.

Mas eu mesmo me esqueci disso, e foi em 1996, em função da crise do desemprego, da crise social, que eu inventei, por assim dizer, uma forma de reintroduzir coletivamente os desempregados na produção, inclusive usando a moeda social. Mas, quando expus a idéia ao senador Aloísio Mercadante, ele me disse que isso já existe e chama-se economia solidária. Depois que eu escrevi sobre isso na imprensa, comecei a receber convites e notícias de que essa é uma preocupação no país inteiro, sobretudo na Igreja. A Igreja foi pioneira com o socialismo cristão, que nunca abandonou a idéia da autogestão, do desenvolvimento comunitário. E a Igreja brasileira é extraordinariamente progressista, sob influência da teologia da libertação. Acho que não há nenhum país como o Brasil. A teologia da libertação existe em toda a América Latina e mesmo fora, mas aqui é mais forte, o que deve ter contribuído para o desenvolvimento tanto teórico quanto prático da economia solidária no Brasil.

P. de S. O. - Agora a gente sabe também, Paul, que você não é um homem de gabinete; quer dizer, você é uma pessoa que sai, que viaja pelo Brasil todo e, sobretudo nesses anos, nesses últimos anos liderando a Secretaria, você deve ter visitado inúmeros empreendimentos solidários. Gostaria que você contasse alguma experiência, alguma coisa que você viu de pessoas construirem solidariamente, coisas que, de alguma maneira, tocaram seu coração.

P. S. - É que eu nunca vivi em comunidade. Essa é uma experiência que eu nunca fiz. Eu os visitei um pouco, mas visitar é uma coisa muito alienada. As pessoas se reúnem, respondem às perguntas, contam coisas, mas eu não tenho nenhuma experiência do tipo que você está falando. Claro, visitar Catende é emocionante.. Suas terras cobrem praticamente cinco municípios e líderes de Catende disputam as prefeituras municipais, são vereadores. Quer dizer, a vida política, a vida do PT, naquela região de Pernambuco, têm um enorme empreendimento coletivo e que é coletivo conscientemente e por opção. Opção que se reafirma. O que me emociona, por exemplo, em Catende, vem também de uma dissertação de mestrado do Fernando Kleiman, em cuja banca eu estive e participei bastante. Agora, não tenho experiências pessoais dessa natureza que você está supondo.

P. de S. O. - Nem relatos junto a essa população?

P. S. - Bem, relatos sim, eles me deixam muito emocionados mesmo. Essa comuna em Kassel, estive várias vezes lá. Vou dar um exemplo concreto: a última vez em que eu lá estive foi quando houve o primeiro grande Congresso de Economia 
Solidária Alemão. Surgiu uma conversa sobre o que está acontecendo com os filhos e eu estava falando exatamente com o marido de uma brasileira que estuda e vive lá. Ele disse: "Não, os filhos vão fazer a vida deles; não vão ficar aqui, não querem saber da comuna". É tipicamente a chamada revolta da adolescência, o adolescente quer mostrar que é diferente dos pais. Eles estão fazendo uma política de ampliar a comuna trazendo gente interessada, fazendo reuniões, seminários, mas não contam com os filhos deles. Isso é uma coisa comovente porque mostra o respeito que eles têm pelos filhos. Óbvio que eles gostariam que os filhos ficassem, mas não estão querendo forçar.

Enfim, eu diria que esse talvez seja o exemplo que mais me toca. Com toda esta transformação das relações humanas, nós estamos caminhando para uma nova sociedade, que talvez venha a ter características capitalistas também, mas o que dá vigor à economia solidária é essa aspiração de que todo o mundo tem o direito de se realizar enquanto indivíduo dentro de relações coletivas, familiares e econômicas. Acho que o grande desafio da economia solidária, e isso é a resposta à sua pergunta, é como conciliar o máximo de liberdade individual - individual mesmo no sentido de que o individualismo é uma aquisição da humanidade - e ao mesmo tempo de convivência decente, não-competitiva, não-antagônica com os outros seres humanos. Esse é o grande desafio: como realizar condições de felicidade, de realização de cada um.

P. de S. O. - E por fim, Paul, a última pergunta: certamente existem coisas importantes das quais nós falamos, mas existem também coisas importantes que eu posso ter me esquecido de perguntar. Assim, gostaria que você usasse esse espaço justamente para falar de coisas importantes das quais nós não falamos.

P. S. - A única coisa importante que eu acrescentaria seria sobre educação democrática, que é uma coisa muito ligada à economia solidária e que envolve crianças desde a mais tenra idade, desde quatro anos de idade, três anos de idade. Meu neto está nessa fase, em que a escola é realmente uma comunidade chamada república de crianças, em que se pratica autogestão e na qual meu neto, que é um pirralho de cinco anos, concorre, ou seja, tem o mesmo peso que os adultos que tomam conta das crianças e são educadores. Houve uma eleição na escola dele, ele se candidatou e recebeu gloriosamente apenas o voto dele. Mas ele não ficou triste, achou que a experiência era válida. O Lucas é totalmente sociável. Já a prima dele, que também é minha neta, é diferente; ela é tímida, muito fechadinha. Enfim, as pessoas são diferentes e num ambiente de liberdade e de respeito, inclusive por serem pequenas, com suas vontades, elas respondem cada uma à sua maneira, mas respondem de uma forma muito positiva.

\section{Notas}

1 Acabaram descobrindo que havia uma lei nos Estados Unidos que dá um incentivo fiscal a trabalhadores que compram a própria empresa. Essa não precisa estar em crise. Se os empregados tiverem um fundo de poupança ou de pensão, podem adquirir a maioria das ações da empresa. Esse tipo de operação financeira chama-se Buy-out. A empresa passa a ser dirigida por gerentes escolhidos pelos novos acionistas, mas não precisa ser em autogestão. 
2 Termo de Ajuste de Conduta é um acordo que o Ministério Público faz com alguma entidade faltosa e que consiste na promessa formal desta última de emendar sua conduta segundo os compromissos especificados no Termo. Atualmente, proíbe as cooperativas de disputar serviços terceirizados do governo federal porque elas não são obrigadas a cumprir a legislação trabalhista.

3 Lei que estabelece normas gerais relativas ao tratamento tributário favorecido, acesso a crédito, tecnologia e compras governamentais a ser dispensado às microempresas $\mathrm{e}$ empresas de pequeno porte no âmbito da União, dos Estados, do Distrito Federal e dos Municípios, mediante regime único de arrecadação.

4 YUNUS, Muhammad. O banqueiro dos pobres. Trad. M. C. G. Cupertino. São Paulo: Ática, 2000.

Paul Singer (@-paul.singer@mte.gov.br) é autor, entres outras, das seguintes obras: Introdução à economia solidária (São Paulo, Fundação Perseu Abramo, 2002); Utopia militante: repensando o socialismo (Petrópolis, Vozes, 1998); Repartição da renda-ricos e pobres sob o regime militar (Rio de Janeiro, Zahar, 1986); A formação da classe operária (São Paulo, Atual, 1985); Economia politica do trabalho (São Paulo, Hucitec, 1977); A crise do milagre (Rio de Janeiro, Paz e Terra, 1976). 